\title{
Number of Regional Accounting Firms and Audit Fees-Based on the Experience Data of Listed Companies in China in 2016
}

\author{
Hongying Fang \\ South China University of Technology, Guangzhou, China \\ Email: fanglingxue@163.com
}

How to cite this paper: Fang, H.Y. (2019) Number of Regional Accounting Firms and Audit Fees-Based on the Experience Data of Listed Companies in China in 2016. American Journal of Industrial and Business Management, 9, 592-608.

https://doi.org/10.4236/ajibm.2019.93041

Received: March 6, 2019

Accepted: March 17, 2019

Published: March 20, 2019

Copyright $\odot 2019$ by author(s) and Scientific Research Publishing Inc. This work is licensed under the Creative Commons Attribution International License (CC BY 4.0).

http://creativecommons.org/licenses/by/4.0/

\begin{abstract}
There are many research literatures on the influencing factors of auditing firms' audit fees, but their influence on audit fees is rarely studied from geographical factors. This paper studies the relationship among the number of regional accounting firms, whether they are local and audit fees, and uses the 2016 A-share listed companies as a sample to collect the number of accounting firms in the cities where the listed companies are located through the Chinese CPA industry management information system; the CPA determines whether it is a local firm. The empirical results show that the number of regional accounting firms is significantly and positively related to audit fees. The greater the number of firms in the region, the higher the audit fees the company will pay. Moreover, this phenomenon is more prominent in the companies who employ local audits. Further research found that the increase in audit fees in the region is a significant manifestation of the improvement in audit quality.
\end{abstract}

\section{Keywords}

Number of Regional Accounting Firms, Audit Fees, Local Firms, Off-Site Firms, Audit Quality

\section{Introduction}

For a long time, the audit fees of accounting firms have been a hot issue in the domestic and international audit market research. Since Simunic established a classic model of audit pricing, scholars' research on audit fees has gradually matured. Most of the literatures at home and abroad focus on the general factors affecting audit fees, such as the size of customers, the complexity of customer 
business, inherent risks, financial risks, whether it is international four, audit tenure, firm size, etc. The impact achieves as high as $57 \%$ [1]. There are also a few domestic literatures that empirically study the relationship between earnings management and audit fees, and find that audit fees are positively related to earnings management to a certain extent. However, few literatures have studied the influence of geographical factors on audit fees. However, in recent years, many large accounting firms have set up branches in various provinces and cities. Local small accounting firms have emerged continuously, and the number of accounting firms in the region has been increasing year by year. The phenomenon of local auditing is also becoming more common. Does the number of regional firms affect audit fees? Is there a connection between the audit fee and the location? This is the core issue of this article. This article takes the 2016 Shanghai \& Shenzhen A-share listed company as a sample, manually collects the number of accounting firms in the city where the listed company is located, and confirms whether it belongs to the local office by the location of the firm that signed the CPA service, and then studies the relationship between the number of regional firms and audit fees, and what the adjustment effect of whether it is audited locally have on audit fees. The empirical results show that the number of regional accounting firms has a significant positive impact on audit fees, and local audits have reinforced this impact. The greater the number of firms, the higher the audit fees, which indicates that the higher the audit quality in the region. The greater number of firms will help to improve the audit quality in the region. This paper firstly proposes the influencing factors of audit fees from the perspective of the number of accounting firms. On one hand, it enriches the theoretical research on the impact of regional factors on audit fees, and on the other hand, it has guiding significance for the government to regulate the operation of the audit market. The organizational structure of this paper is as follows: first review the literature on the factors affecting the audit fees and find out their merits and deficiencies, then propose three hypotheses based on the theoretical knowledge, and then construct a model for empirical testing, in addition get further analyzing on the nature of the phenomenon, also test the robustness of the model and finally draw conclusions and recommendations.

\section{Literature Review}

Foreign research on audit pricing has been more than 30 years old. The empirical study of audit fees began with Simunic (1980). By constructing a multiple linear regression model of the factors affecting audit fees, he found that the customer's asset size is the most important factor affecting audit fees, followed by the customer business complexity, asset-liability ratio, audit opinion type, company inherent risk and audit risk, etc. However there is no significant correlation between audit fees and the return on net assets (ROE), the audit term and the size of the firm. Later, based on Simunic's classic audit fee model, scholars continued to add new variables to study the impact of a particular factor on audit 
fees [1]. Francis (1984) conducted an empirical study of Australian listed companies and found that the total assets at the end of the trial, the number of subsidiaries, and the accounting firm's brand had significant impacts on audit fees [2]. Chen, Ezzamel et al. (1993) studied the audit fees of listed companies in the UK by establishing a multiple linear regression model. The conclusions indicate that the relationship between the equity dispersal, the auditing time measured by the reporting date and the reporting date interval, the accounting firm's place of registration, the accounting firm's brand and the auditing expenses are significant [3]. Abbott et al. (2003) studied the impact of audit committee characteristics on audit fees. The results of the study indicate that the proportion of independent directors and members with financial background in the audit committee is positively correlated with audit fees [4]. Joseph et al. (2010) studied the audit fees from the perspective of the characteristics of the board of directors of listed companies, and found that the stronger the independence of the board of directors, the higher the diligence and the more professional, the more audit fees are paid [5].

Domestic research on audit fees began with Zhenlin Wang, and has also experienced more than a decade of development. Most of the research is based on foreign research results. By constructing an audit fee model, it is tested whether the general influencing factors of audit fees also affect China's audit pricing. Zhenlin Wang (2002) conducted an empirical study through questionnaire survey. The results show that the main influencing factors of audit fees are the size and complexity of listed companies, the inherent risks of listed companies, the proportion of shares outstanding, the proportion of state-owned shares, the brand of accounting firms, and the audit term. Whether or not the accounting firm has changed also significantly affects the audit fee [6]. Bin Liu, Jianzhong Ye, and Yingyi Liao (2003) analyzed the data of listed companies in China in 2001 by constructing multiple regression models. The results show that the scale of listed companies, the complexity of economic business and the place of registration of accounting firms have a positive impact on audit fees, and whether the company has incurred losses. The relationship between the type of audit opinion and the audit fee is not significant, neither is the size of the accounting firm's brand [7]. After an empirical study by Houjun Han and Shengchun Zhou (2003), it was found that the relationship between the size of the listed company, number of subsidiaries, asset-liability ratio, whether the non-standard audit opinion was issued and the audit fees were significant. In addition, the company's inherent risks such as inventory, the proportion of receivables to total assets are not related to audit fees, and the relationship between the company's return on net assets and audit fees is not significant [8]. Jiangna Qi (2004) focused on the impact of accounting firms' brand on audit fees. The conclusions show that the international four major audit fees are higher than local accounting firms, and they call on domestic accounting firms to focus on brand building [9]. Xiaoping Zhu and Qian Yu (2004) identified the impact factors of audit fees through statistical analysis, and found out the total assets of listed companies, the number of 
subsidiaries, whether they were ST, whether they issued foreign shares, the registered level of listed companies, the accounting firm's brand, and the audit term, are significant factors in the impact of audit fees [10]. Ying Lv and Lianmeng Lv (2010) conducted an empirical study on the data of Shenzhen A-share listed companies, and found that the size of the audited units, the number of branches, the size of the accounting firm, and the willingness to maintain and protect the licenses are positively related to the audit fees. The proportion of each asset is not related to the audit fees [11]. Bing Wang and QingquanXin (2010) examined the differences in the audit quality and audit fees of the local firms and off-site firms through the data of the accounting firm's branch office. The research conclusions show that the off-site firms' audit quality and audit fees are lower. And the smaller the size of the branch, the lower the audit quality and audit fees [12].

Throughout the research results of scholars at home and abroad, we can see that the general influencing factors of audit fees are the size of the client, the complexity of the business, the financial risk of the listed company, the type of audit opinion and whether the auditor is international, and the profit of the listed company. There is no significant correlation between capacity and the proportion of assets. Beginning with the classic paradigm of Simunic (1980), the research on audit fees has expanded from the general main influential factors to certain specific factors. Although many research conclusions have not yet been agreed, they have promoted the development of audit fees research. At present, most of the literature focuses on the general influential factors of audit fees, mainly to study the impact of corporate characteristics and audit firm characteristics on audit fees. Specific factors are mainly concentrated on the nature of property rights, governance structure or government control [13], rarely from the external geographical factors to study the impact factors of audit fees, only a few literature research on branch audit and the geographical proximity of the firm which impact on audit quality. However, the number of local offices has been mushrooming in the current practice of auditing, and theoretical research has lagged behind. This paper puts the geographical factor of the number of firms into Simunic's audit fee model for the first time, then studies the regional factors including the number of accounting firms and the impact of local firms by controlling the general influencing factors of audit fees. On this basis, explores the reasons for the changes and make relevant recommendations.

\section{Theoretical Analysis and Research Hypothesis}

With regard to the definition of audit fees, foreign audit fees consist of three parts. The first is the cost of audit activities, that is, the amount spent in the audit process and the cost of issuing reports. The second is the audit risk premium, that is, the compensation caused by the audit failure of the audited unit. Risk and its impact on reputation; the third is the brand premium of accounting firms, well-known accountants represent higher audit quality, and the audit fees 
required are correspondingly higher. Domestically, the audit fees are subject to government-guided prices. The price standards are determined by "fixed price \pm floating percentage", "fixed price", "price by capital and time", etc. The price changes vary widely and there is no uniform charging standard. The empirical research was conducted by selecting the audit fees disclosed in the annual reports of listed companies. Regarding the definition of the number of regional offices, in order to unify the caliber, the county-level cities are no longer listed separately according to the classification and statistics of the prefecture-level cities to which the listed companies are located. Regarding the definition of the regional nature of accounting firms, one is directly divided by provinces, municipalities directly under the Central Government and autonomous regions. Most of the literature studies use this method to determine the local area; the other is that the listed company and the accounting firm belong to the same administrative region. And half of the total assets of all clients of the accounting firm are from the region and are recognized as local. This paper adopts the first definition method to divide the local and remote locations according to whether the area of the accounting firm that the signed auditor serves is the same as the area where the listed company is located.

- Number of accounting firms and audit fees

The more the number of accounting firms in the region and the fiercer competition in the industry, the more the accountants will improve their own practice. The better the quality control system of the accounting firm, the higher the audit cost required, and the inevitable compensation from the client's audit fees cost. In addition, in order to ensure the sustained and healthy development of China's economy, the CSRC's superquality audit requirements, and audit fees will increase to ensure higher audit quality. On this basis, we propose the hypothesis:

$H 1$ : The audit fees will increase as the number of accounting firms in the region increases, while other conditions remain unchanged.

- Whether the local affirm and the audit fee

The audit cost is significantly and positively related to the audit workload and audit difficulty. The audit workload is generally determined by the size of the audited entity and the complexity of the business. The audit difficulty is related to the auditor's familiarity with the listed company and the difficulty of conducting substantive tests. Relevant to the extent, the local accounting firm is close to the listed company, has a natural geographical advantage, can save audit costs such as accommodation expenses and travel expenses, and the auditor knows more about the listed company, understands the local fiscal tax law system, and communicates with the audit process. More convenient, audit evidence is more accessible, which will lead to a significant reduction in audit costs, improved audit efficiency, and a corresponding reduction in audit fees for listed companies. If the accounting firm is in the same area as the listed company, it can effectively reduce information asymmetry, and various financial and tax law 
information can be shared. It is easier to find the risks that listed companies may have, reduce the risk of audit failure, and compensate for the risk premium and reputation risk. The premium is correspondingly reduced, which in turn reduces audit costs. Therefore, we propose the hypothesis:

$H 2$ : The audit fees of local accounting firms are lower when other conditions remain unchanged.

- The number of firms, whether they are local and audit fees

Non-audit services also have a certain impact on audit fees. Simunic (1984) found through empirical research that the audit fees paid by customers who purchase audit services and non-audit services in the same accounting firm are higher than the audit fees paid by customers who only purchase audit services [1]. The greater the number of regional accounting firms, the more non-audit services are provided in the accounting market in this region. If a listed company hires a local audit, the probability of purchasing non-audit services increases, which will result in an increase in audit fees. In addition, local audits have geographical advantages and operational advantages, and listed companies are willing to pay higher audit fees in order to maintain long-term relationships with the local accounting affirms. Therefore, we propose the hypothesis:

$H 3$ : Under other conditions, the more the number of regional accounting firms audited locally, the higher the audit fees, and the local audits increase the impact of the number of firms on audit fees.

\section{Research Methodology}

\subsection{Data}

The data in this paper comes from the Wind database and the Chinese CPA industry management information system. Taking the 2016 Shanghai and Shenzhen A-share listed companies as samples, it excludes: 1) financial listed companies; 2) the listed companies that have not disclosed audit fees. The final valid sample data is 2717. This paper collects the number of accounting firms in the provinces and municipalities where the listed companies are located in the Chinese CPA industry management information system through the registration of the listed companies; and queries the accounting firms served by the certified CPA through the industry management information system to determine Whether the accounting firm it serves belongs to the local office. When the signed CPA does not belong to the same firm, it is judged whether it belongs to the local office by the address of the audit institution disclosed in the annual report. In this paper, $1 \%$ of the continuous variables involved in the model are truncated.

\subsection{Empirical Model}

- Dependent variable: the natural logarithm of the audit fee (Lnfee)

This paper selects all the listed company data that disclosed the audit fees in the 2016 Shanghai and Shenzhen A-share market, and takes its natural logarithm 
as the explanatory variable.

- Independent variable

This paper studies the relationship between the number of regional accounting firms and the audit fees, and selects the number of firms in the city where the listed company is registered and whether it is a local test variable. The arguments in this paper are described as follows:

Lnnum: The natural logarithm of the number of urban accounting firms. The number of provincial and municipal accounting firms is based on the statistics of the Chinese CPA Industry Management Information System on December 31, 2017;

Local: is a dummy variable. When the signature auditor and the listed company belong to the same city, it is the local office, Local takes 0 ; when the signature auditor is off-site firm, Local takes 1.

- Control variables

Combined with the research results of the existing literature, in order to control other related variables that may affect audit fees, this paper selects the total assets size, long-term capital debt ratio, total return on assets, asset-liability ratio, receivable ratio, and inventory ratio of listed companies. Whether it is a loss, whether it is issued a non-standard audit opinion, whether the accounting firm belongs to the "International Big Four" as a control variable. The control variables involved in the model are described below:

Lnasset: the natural logarithm of the total assets of the listed company at the end of 2016, representing the size of the audited unit;

Lev: measuring the financial risk of listed companies for the long-term debt-to-liability ratio;

Opinion: a dummy variable, which represents the type of audit opinion. When issuing a non-standard audit opinion, take 1 and when the standard is unqualified, take 0 ;

Big4: it is a dummy variable, which represents the size of an accounting firm. When the firm is international, it will take 1 and the firm will take 0 when it is not international.

This paper draws on Simunic's audit fee model, uses multiple linear regression equations to study the relationship between the number of regional accounting firms and audit fees, and integrates the above research design to construct the following model:

$$
\begin{gathered}
\text { Lnfee }=\alpha 0+\alpha 1 \times \text { Lnnum }+\alpha 2 \times \text { Local }+\alpha 3 \times \text { Lnasset }+\alpha 4 \times \text { Lev } \\
+\alpha 5 \times \text { Opinion }+\alpha 6 \times \text { Big } 4+\sum \text { Industry }+\varepsilon \\
\text { Lnfee }= \\
\beta 0+\beta 1 \times \text { Lnnum }+\beta 2 \times \text { Local }+\beta 3 \times \text { Local } \times \text { Lnnum }+\beta 4 \times \text { Lnasset } \\
+\beta 5 \times \text { Lev }+\beta 6 \times \text { Opinion }+\beta 7 \times \text { Big } 4+\sum \text { Industry }+\varepsilon
\end{gathered}
$$

After controlling the general influencing factors, the industry and the residual $\varepsilon$, this paper predicts that the audit fees will be affected by the number of accounting firms and whether they belong to the local. The more accounting firms in the region, the higher the audit fees; but the negative correlation between local 
auditing and audit fees, and the local the audit will strengthen the impact of the number of accounting firms on audit fees. If this assumption holds, $\alpha 1$ should be a positive number, $\alpha 2$ be a negative number, with $\beta 3>0$ expected.

\section{Empirical Test Results and Analysis}

\subsection{Descriptive Statistical Analysis}

Table 1 presents descriptive statistics for each variable. Through the descriptive statistics of the various observations listed in the table, it can be seen that the annual audit fees of listed companies in 2016 are between 100,000 yuan and 51.58 million yuan, with a large gap, with an average of 1,234,400 yuan. Among the 3002 listed companies, there are 1213 listed companies audited locally and 1789 audited by different places. The audit phenomenon in different places mainly exists in small cities. The local lack of large accounting firms, and listed companies prefer large accounting firms. Conduct an audit. The number of urban accounting firm ranges from 0 to 674 , and the span is also large.

The average number of firms is 162 , which shows that the regional development of accounting firms is uneven. The average size of the company's total assets is 15.4 billion yuan, with a maximum value of 2.4 trillion yuan, and a large number of small and medium-sized listed companies. The average long-term debt-to-equity ratio of listed companies is $14.60 \%$, and the financial risks that may be encountered are small. There are 96 listed companies that have been issued non-standard audit opinions. The audit opinions of the annual reports of most listed companies are standard without reservation. There are 153 listed companies audited by the international four major auditors. The vast majority of listed companies employ domestic accounting firms. It can be seen that the development of local accounting firms has been recognized by the market.

\subsection{Analysis of Multiple Regression Results}

First, it is necessary to verify whether the model is reliable. The reliability of the parameters is determined by collinear diagnosis and measuring the heteroscedasticity of the residual. Generally, tolerance, variance expansion factor (VIF, reciprocal of tolerance) are used as a collinear diagnosis index. The tolerance value is between 0 and 1 . If the value is too small, this independent variable and other self are described. There is a collinear problem between variables. The larger the VIF value, the more obvious the collinear problem is. We can see from Table 2, in model (1), the VIF of each factor is below 10, there is no collinear problem in this study, in model (2), the most VIF are less than 10, there is a cross term, so there is a collinear problem between the two variables, it can be ignored.

Equal variance is the basic assumption of simple linear regression. It can be tested by the residual and regression fit values or the scatter plot between the normalized residual and the normalized predictive value. If there is equal variance, the residuals corresponding to different fitted values the difference 
Table 1. Description of each variable.

\begin{tabular}{cccccc}
\hline Variable & Obs & Min. & Max. & Mean & SD \\
\hline fee & 2717 & $100,000.00$ & $51,580,000.00$ & $1,236,375.88$ & $2,392,096.67$ \\
Lnfee & 2717 & 11.51 & 17.76 & 13.68 & 0.67 \\
Local & 2717 & 0 & 1 & 0.40 & 0.49 \\
num & 2717 & 0 & 674 & 161.99 & 192.06 \\
Lnnum & 2717 & 0 & 6.51 & 4.22 & 1.53 \\
asset & 2717 & $5.26 \mathrm{E}+07$ & $2.40 \mathrm{E}+12$ & $1.54 \mathrm{E}+10$ & $7.42 \mathrm{E}+10$ \\
Lnasset & 2717 & 17.78 & 28.51 & 22.17 & 1.33 \\
Lev & 2717 & -149.47 & 114.91 & 14.60 & 18.41 \\
Opinion & 2717 & 0 & 1 & 0.03 & 0.18 \\
Big4 & 2717 & 0 & 1 & 0.05 & 0.22 \\
\hline
\end{tabular}

Table 2. Collinear diagnosis.

\begin{tabular}{|c|c|c|c|c|c|}
\hline \multirow{2}{*}{$\begin{array}{c}\text { Dependent } \\
\text { variable: Lnfee }\end{array}$} & \multicolumn{2}{|c|}{ Collinear statistic } & \multirow{2}{*}{$\begin{array}{c}\text { Dependent } \\
\text { variable: Lnfee }\end{array}$} & \multicolumn{2}{|c|}{ Collinear statistic } \\
\hline & Tolerance & VIF & & Tolerance & VIF \\
\hline (constant) & & & Lnnum & 0.323 & 3.097 \\
\hline Lnnum & 0.664 & 1.506 & Lnasset & 0.587 & 1.705 \\
\hline Local & 0.700 & 1.428 & Lev & 0.591 & 1.692 \\
\hline Lnasset & 0.587 & 1.704 & Big4 & 0.860 & 1.163 \\
\hline Lev & 0.591 & 1.692 & Opinion & 0.957 & 1.045 \\
\hline Big4 & 0.862 & 1.160 & A & 0.972 & 1.029 \\
\hline Opinion & 0.957 & 1.045 & B & 0.933 & 1.071 \\
\hline A & 0.972 & 1.028 & $\mathrm{C} 1$ & 0.903 & 1.107 \\
\hline B & 0.933 & 1.071 & $\mathrm{C} 4$ & 0.962 & 1.039 \\
\hline $\mathrm{C} 1$ & 0.903 & 1.107 & C9 & 0.813 & 1.229 \\
\hline $\mathrm{C} 4$ & 0.963 & 1.039 & $\mathrm{D}$ & 0.865 & 1.156 \\
\hline C9 & 0.814 & 1.228 & $\mathrm{E}$ & 0.920 & 1.087 \\
\hline $\mathrm{D}$ & 0.866 & 1.154 & $\mathrm{~F}$ & 0.905 & 1.105 \\
\hline $\mathrm{E}$ & 0.920 & 1.087 & G & 0.915 & 1.093 \\
\hline $\mathrm{F}$ & 0.906 & 1.103 & $\mathrm{H}$ & 0.987 & 1.013 \\
\hline G & 0.915 & 1.092 & I & 0.853 & 1.173 \\
\hline $\mathrm{H}$ & 0.987 & 1.013 & K & 0.812 & 1.232 \\
\hline I & 0.853 & 1.173 & $\mathrm{~L}$ & 0.971 & 1.030 \\
\hline $\mathrm{K}$ & 0.812 & 1.231 & M & 0.979 & 1.022 \\
\hline $\mathrm{L}$ & 0.971 & 1.030 & $\mathrm{~N}$ & 0.971 & 1.030 \\
\hline M & 0.980 & 1.020 & $\mathrm{P}$ & 0.993 & 1.007 \\
\hline $\mathrm{N}$ & 0.975 & 1.025 & Q & 0.994 & 1.006 \\
\hline $\mathrm{P}$ & 0.993 & 1.007 & $\mathrm{R}$ & 0.971 & 1.030 \\
\hline Q & 0.994 & 1.006 & $\mathrm{~S}$ & 0.982 & 1.019 \\
\hline $\mathrm{R}$ & 0.971 & 1.030 & Local & 0.027 & 37.415 \\
\hline S & 0.982 & 1.019 & Lnnum $\times$ Local & 0.021 & 46.618 \\
\hline
\end{tabular}


should be approximately the same, that is, the points in the figure are evenly distributed, and no special distribution shape will appear. If the residual points are not evenly distributed, forming a funnel or a fan shape, then the regression does not have equal variance. In Figure 1, the results of this study show that the points in the scatter plot of the standardized residuals and the standardized predictive values are evenly distributed, although they are relatively concentrated in the central part, they are not very serious. Based on this, we believe that the regression meets the basic assumptions of equal variance.

As can be seen from the following histogram (Figure 2), the normalized residual of the regression approximates a normal distribution. Both the scatter plot and the normal distribution histogram show that the residual has independence and does not change with the independent variable, which indicates that the residual has no heteroscedasticity, and the regression parameter estimator has good statistical properties, so the model is reliable.

From Table 3, the Durbin-Watson test value for model (1) was 1.925, in model (2) it's 1.927. In general, the Durbin-Watson test values are distributed between 0 and 4 . The closer to 2, the more likely the observations are independent of each other. That is, the observations of simple linear regression in this study are independent of each other.

In Table 3, the adjusted R-square of the model is higher than 0.56 , which indicates that the model's explanatory power to the research object is as high as $56 \% . F=143.215$, and significant at the level of $1 \%$, indicating that the equation has a high degree of fit, both of which show that the model is more convincing.

The regression results of model (1), model (2) are shown in Table 3. Based on the positive or negative of $\alpha 1, \alpha 2$ and $\beta 3$, the number of regional firms and the impact of local audit fees are determined. According to Table $3, \alpha_{1}$ is 0.019. After controlling the assets size, financial risk, audit opinion type and firm size of the listed company, the number of regional firms and the audit fees are significant at the $1 \%$ confidence level, showing a positive correlation. This is consistent with our hypothesis 1 conclusion that the more regional accounting firms, the higher the audit fees paid by the audited entities. Although $\alpha_{2}$ is negative, the regression result is not significant. Therefore, there is no significant correlation between local and audit fees. Local auditing does not bring more advantages. Audit fees are not reduced. Hypothesis 2 is not established. The possible cause of this phenomenon is that the selected sample data is not enough to show a significant negative correlation. The number of regional firms and the coefficient of the intersection of the two variables are 0.05 , which is positive, indicating that the local audit can strengthen the impact of the number of regional firms on audit fees, the number of firms audited locally, the higher the number of firms, the higher the audit fees paid, and Hypothesis 3 is verified. In addition, the control variables of the two models are significantly correlated at the level of $1 \%$, indicating that the non-standard audit opinion, the international four major audits will result in an increase in audit fees, the company size and audit fees are positively correlated, and the long-term debt-to-asset ratio is negatively related to 
Scatter plot

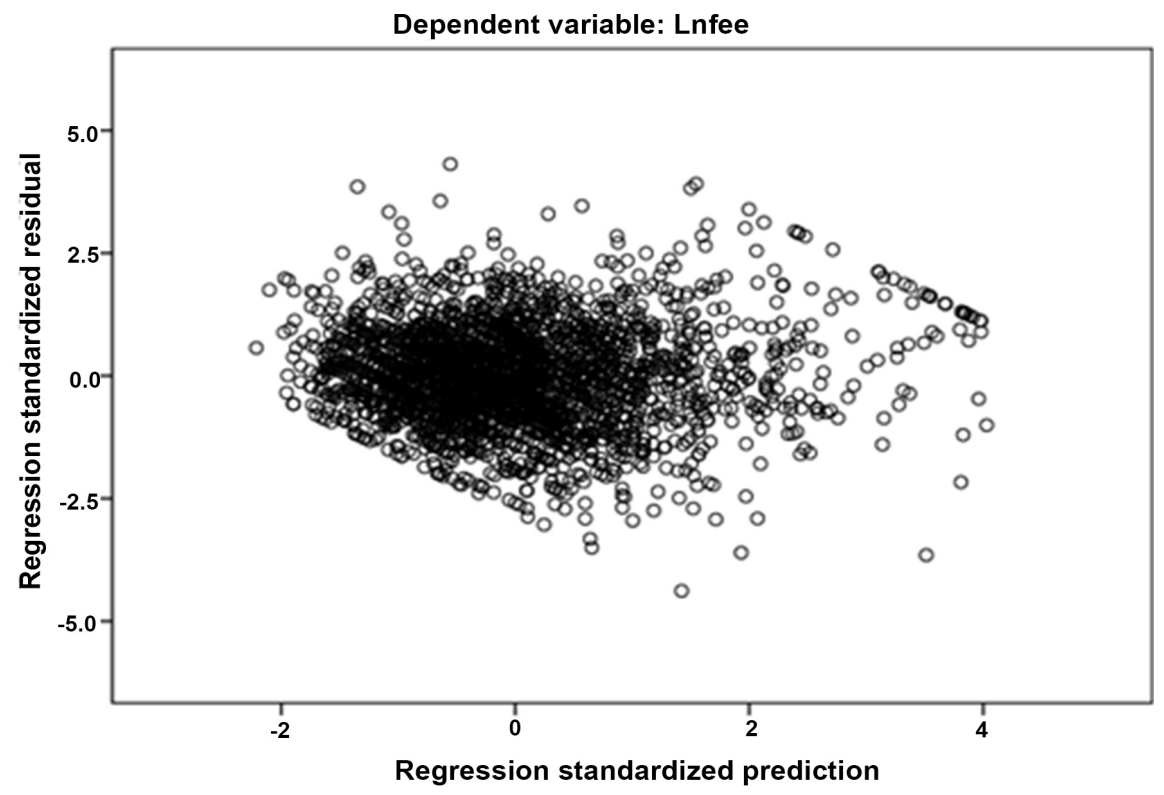

Figure 1. Scatter plot of residual.

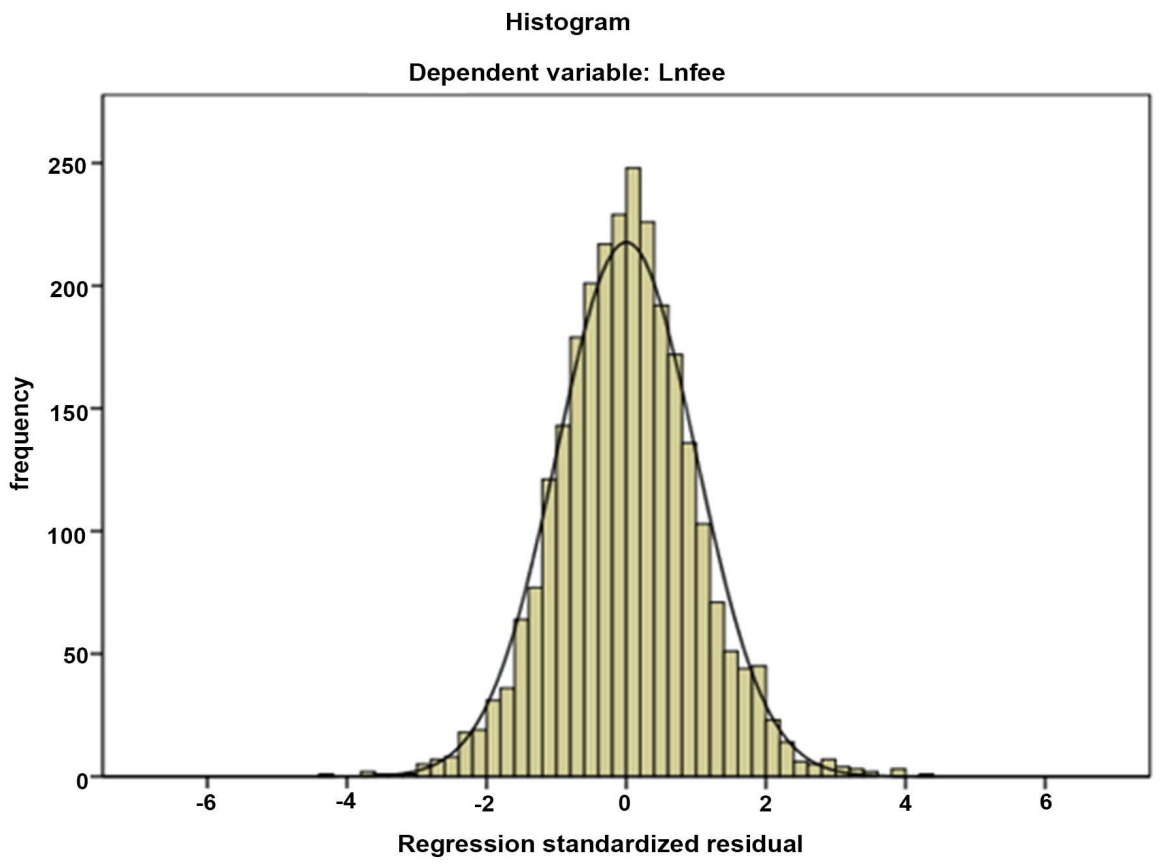

Figure 2. Histogram of residual.

audit fees. The relationship between these variables and audit fees is consistent with previous research results, further indicating that the model constructed is reasonable.

\subsection{Further Analysis}

What is the relationship between audit fees and the number of firms? What is the number of firms in the region that affects audit fees? In the past, scholars 
Table 3. Regression of the number of accounting firms and audit fees.

\begin{tabular}{|c|c|c|c|c|c|}
\hline Ln fee & (1) & (2) & (3) & (4) & (5) \\
\hline Constant & $\begin{array}{l}13.518^{* * *} \\
(378.483)\end{array}$ & $\begin{array}{l}13.675^{* * *} \\
(856.009)\end{array}$ & $\begin{array}{l}5.659^{* * *} \\
(30.553)\end{array}$ & $\begin{array}{l}5.646^{* * *} \\
(30.396)\end{array}$ & $\begin{array}{l}5.704^{* * *} \\
(30.603)\end{array}$ \\
\hline Lnnum & $\begin{array}{c}0.046^{* * *} \\
(5.783)\end{array}$ & & $\begin{array}{c}0.016^{* * *} \\
(2.803)\end{array}$ & $\begin{array}{c}0.019^{* * *} \\
(2.837)\end{array}$ & $\begin{array}{c}0.009 \\
(1.169)\end{array}$ \\
\hline Local & & $\begin{array}{c}0.091^{* * *} \\
(3.620)\end{array}$ & & $\begin{array}{l}-0.019 \\
(-0.922)\end{array}$ & $\begin{array}{c}-0.267^{* * *} \\
(-3.238)\end{array}$ \\
\hline Lnnum $\times$ Local & & & & & $\begin{array}{c}0.050^{* * *} \\
(3.105)\end{array}$ \\
\hline Opinion & & & $\begin{array}{c}0.168^{* * *} \\
(3.656)\end{array}$ & $\begin{array}{c}0.167^{* * *} \\
(3.624)\end{array}$ & $\begin{array}{c}0.169^{* * *} \\
(3.669)\end{array}$ \\
\hline Lnasset & & & $\begin{array}{l}0.356^{\star * *} \\
(42.144)\end{array}$ & $\begin{array}{l}0.357^{* * *} \\
(42.151)\end{array}$ & $\begin{array}{l}0.356^{* * *} \\
(42.071)\end{array}$ \\
\hline Lev & & & $\begin{array}{l}-0.0004 \\
(-0.573)\end{array}$ & $\begin{array}{l}-0.0004 \\
(-0.600)\end{array}$ & $\begin{array}{l}-0.0004 \\
(-0.564)\end{array}$ \\
\hline Big 4 & & & $\begin{array}{l}0.543^{\star * *} \\
(13.921)\end{array}$ & $\begin{array}{l}0.543^{* * *} \\
(13.913)\end{array}$ & $\begin{array}{l}0.534^{* * *} \\
(13.679)\end{array}$ \\
\hline Industry & & & control & control & control \\
\hline Durbin-Watson & & & & 1.925 & 1.927 \\
\hline Adj. $R^{2}$ & 0.012 & 0.004 & 0.567 & 0.567 & 0.568 \\
\hline $\mathrm{F}$ & & & & 143.215 & 138.291 \\
\hline No.of obs. & 2716 & 2716 & 2716 & 2716 & 2716 \\
\hline
\end{tabular}

Note: ${ }^{* * *},{ }^{* *}$, and ${ }^{*}$ indicate that the regression coefficient is significant at the $1 \%, 5 \%$, and $10 \%$ levels, respectively.

believed that the higher the audit quality, the higher the audit fees, and the positive correlation between audit quality and audit fees. In order to further explore the relationship, the author used the excess charge to replace the audit quality, and conducted an empirical study on the relationship between the excess charge and the number of regional firms. The results showed that the more the number of accounting firms in the region, the more serious the overcharge was, and the local audit increased the excess. The fee indicates that the increase in audit fees is an indication of the improvement in audit quality. The specific regression results are shown in Table 4.

From Table 4, the overcharge and the number of firms are positively correlated at a significant level of $1 \%$, opinion, asset, big 4 also has a significant correlation with overcharge, which all indicate positive correlation with audit quality.

\subsection{Robustness Test}

In order to ensure the reliability of the model, we also carried out a robustness test. Firstly, according to whether the province is defined as a local institution, the relationship between the number of accounting firms in the province where the listed company is located and the audit fees are examined. After controlling other relevant variables, a consistent conclusion is obtained. Hypothesis 1 and Hypothesis 3 are established, and hypothesis 2 is not established. As shown in Table 5, the first two columns, the regression model is significant and the credibility is high. The positive relationship between the number of provincial firms 
Table 4. Regression of the number of accounting firms and overcharge.

\begin{tabular}{cccc}
\hline Overcharge & $(1)$ & $(2)$ & $(3)$ \\
\hline \multirow{2}{*}{ constant } & $-10.164^{* * *}$ & $-10.147^{* * *}$ & $-10.062^{* * *}$ \\
& $(-33.139)$ & $(-32.989)$ & $(-30.582)$ \\
Lnnum & $0.028^{* * *}$ & $0.023^{* *}$ & 0.008 \\
& $(2.978)$ & $(2.073)$ & $(0.643)$ \\
Local & & $0.024(0.696)$ & $-0.338^{* *}$ \\
& & & $(-2.480)$ \\
Lnnum $\times$ Local & & & $0.074^{* * *}$ \\
Opinion & $0.217^{* * *}$ & $0.219^{* * *}$ & $(2.745)$ \\
& $(2.85)$ & $(2.871)$ & $0.222^{* * *}$ \\
Lnasset & $0.450^{* * *}$ & $0.449^{* * *}$ & $(2.910)$ \\
& $(32.114)$ & $(32.072)$ & $0.448^{* * *}$ \\
Lev & 0.0003 & 0.0004 & $(31.985)$ \\
Big 4 & $(0.338)$ & $(0.358)$ & 0.0004 \\
& $1.333^{* * *}$ & $1.334^{* * *}$ & $(0.391)$ \\
Industry & $(20.627)$ & $(20.63)$ & $1.321^{* * *}$ \\
Adj.R & control & control & $(20.408)$ \\
No. of obs. & 0.479 & 0.479 & control \\
& 2716 & 2716 & 0.481 \\
& & & 2716
\end{tabular}

Note: ${ }^{* *},{ }^{* *}$, and ${ }^{*}$ indicate that the regression coefficient is significant at the $1 \%, 5 \%$, and $10 \%$ levels, respectively.

Table 5. Regression results of robustness test.

\begin{tabular}{ccccccc}
\hline Lnfee & Prov.(1) & Prov.(2) & Manu.(3) & Manu.(4) & Big10(5) & Big10(6) \\
\hline \multirow{2}{*}{ Constant } & $5.471^{* * *}$ & $5.657^{* * *}$ & $6.278^{* * *}$ & $6.302^{* * *}$ & $4.953^{* * *}$ & $5.038^{* * *}$ \\
& $(27.574)$ & $(26.194)$ & $(28.018)$ & $(28.105)$ & $(27.281)$ & $(27.613)$ \\
Lnnum & $0.042^{* * *}$ & 0.009 & $0.02^{* *}$ & 0.013 & $0.024^{* * *}$ & 0.011 \\
& $(3.114)$ & $(0.453)$ & $(2.536)$ & $(1.486)$ & $(3.486)$ & $(1.419)$ \\
Local & 0.024 & $-0.317^{* *}$ & -0.007 & $-0.204^{*}$ & -0.028 & $-0.340^{* * *}$ \\
Lnnum $\times$ & $(1.353)$ & $(-2.006)$ & $(-0.262)$ & $(-1.936)$ & $(-1.322)$ & $(-4.036)$ \\
Local & & $0.058^{* *}$ & & $0.04^{*}$ & & $0.063^{* * *}$ \\
Opinion & $0.176^{* * *}$ & $(2.170)$ & & $(1.932)$ & & $(3.825)$ \\
& $(3.820)$ & $(3.873)$ & $(2.845)$ & $(2.934)$ & $(3.606)$ & $(3.663)$ \\
Lnasset & $0.356^{* * *}$ & $0.356^{* * *}$ & $0.328^{* * *}$ & $0.328^{* * *}$ & $0.385^{* * *}$ & $0.383^{* * *}$ \\
& $(42.062)$ & $(42.102)$ & $(32.038)$ & $(32.061)$ & $(46.225)$ & $(46.039)$ \\
Lev & -0.0001 & -0.0001 & 0.0005 & 0.0004 & -0.001 & -0.001 \\
& $(-0.245)$ & $(-0.156)$ & $(0.594)$ & $(0.541)$ & $(-1.134)$ & $(-1.081)$ \\
Big4 & $0.551^{* * *}$ & $0.546^{* * *}$ & $0.498^{* * *}$ & $0.493^{* * *}$ & $0.126^{* * *}$ & $0.124^{* * *}$ \\
Industry & $(14.145)$ & $(14.015)$ & $(9.506)$ & $(9.402)$ & $(7.304)$ & $(7.234)$ \\
Adj. $\mathrm{R}^{2}$ & control & control & - & - & control & control \\
No. of obs. & 0.568 & 0.568 & 0.518 & 0.519 & 0.545 & 0.547 \\
\hline
\end{tabular}

Note: ${ }^{* *},{ }^{* *}$, and ${ }^{*}$ indicate that the regression coefficient is significant at the $1 \%, 5 \%$, and $10 \%$ levels, respectively. In column (5) \& (6), Big4 means Big 10.

and the audit fees is significant at the $1 \%$ level, and the coefficient of the intersection is $95 \%$ reliability.

Secondly, we verify the sub-samples by industry. Take the listed companies in 
the manufacturing industry as an example to control the impact of industry and other related variables on audit fees. Multivariate linear regression is performed. The regression results are shown in Table 5, the third and fourth columns, except Hypothesis 2, the other two assumptions are established. Among them, the number of regional firms significantly affect the audit fees at the $5 \%$ level, and the number is significantly positively correlated with whether the local transactions and the audit fees are within the 95\% confidence interval. The test results show that in the manufacturing industry, the number of regional firms also has a significant impact on audit fees. The more firms, the higher the audit fees; and the local audit will enhance this positive impact.

Also, we change the control variables from whether it is international or not to the top ten in China. The top ten rankings are based on the information of the top 100 accounting firms disclosed in 2016. After controlling other identical variables, the results are still very significant. In Table 5, the last two columns, it can be seen that all the observations are significant at the level of $1 \%$ except for the local ones. It can be verified that the model is reliable and the regression results have Robustness.

In addition, the empirical explanatory variables used in this paper are municipal data, and there may be endogenous problems caused by the imbalance of development in various cities. The results of previous empirical studies indicate that the better the regional economic situation, the higher the audit fees. To control the impact of the city's economic development on the number of firms, we used a placebo test to test such problems. Drawing on the placebo test method of Li et al. (2016), this paper chooses to reorganize the number of firms, and the number of firms after random allocation no longer implied the level of economic development of the city. The number of randomly assigned firms is returned to the financial data of the listed company. If the positive correlation between the number of firms and the audit fees is still significant, it indicates that the regional economic development level will not affect the audit fees. Pseudo-correlation. On the contrary, if the number of firms no longer significantly affects audit fees, it indicates that there is no endogenous problem caused by the imbalance of economic development.

The regression analysis of the model (1) is performed using 10,000 randomly assigned data. As shown in Figure 3, the sig value of the coefficient of the Ln num index is more than $90 \%$ greater than 0.1 , indicating that in the case where the control variable is significant, the firm Most of the significant coefficient of quantity is higher than $10 \%$, which means that there is no significant correlation between the number of firms and audit fees. In addition, in the regression results of the model (2), Figure 4 shows that the coefficient of more than $85 \%$ of the intersection terms is not significant, indicating that the local audit has little effect on the relationship between the number of firms and the audit fees. Therefore, there is no endogenous influence variable in this paper, and it is assumed that the test conclusion has certain robustness. 


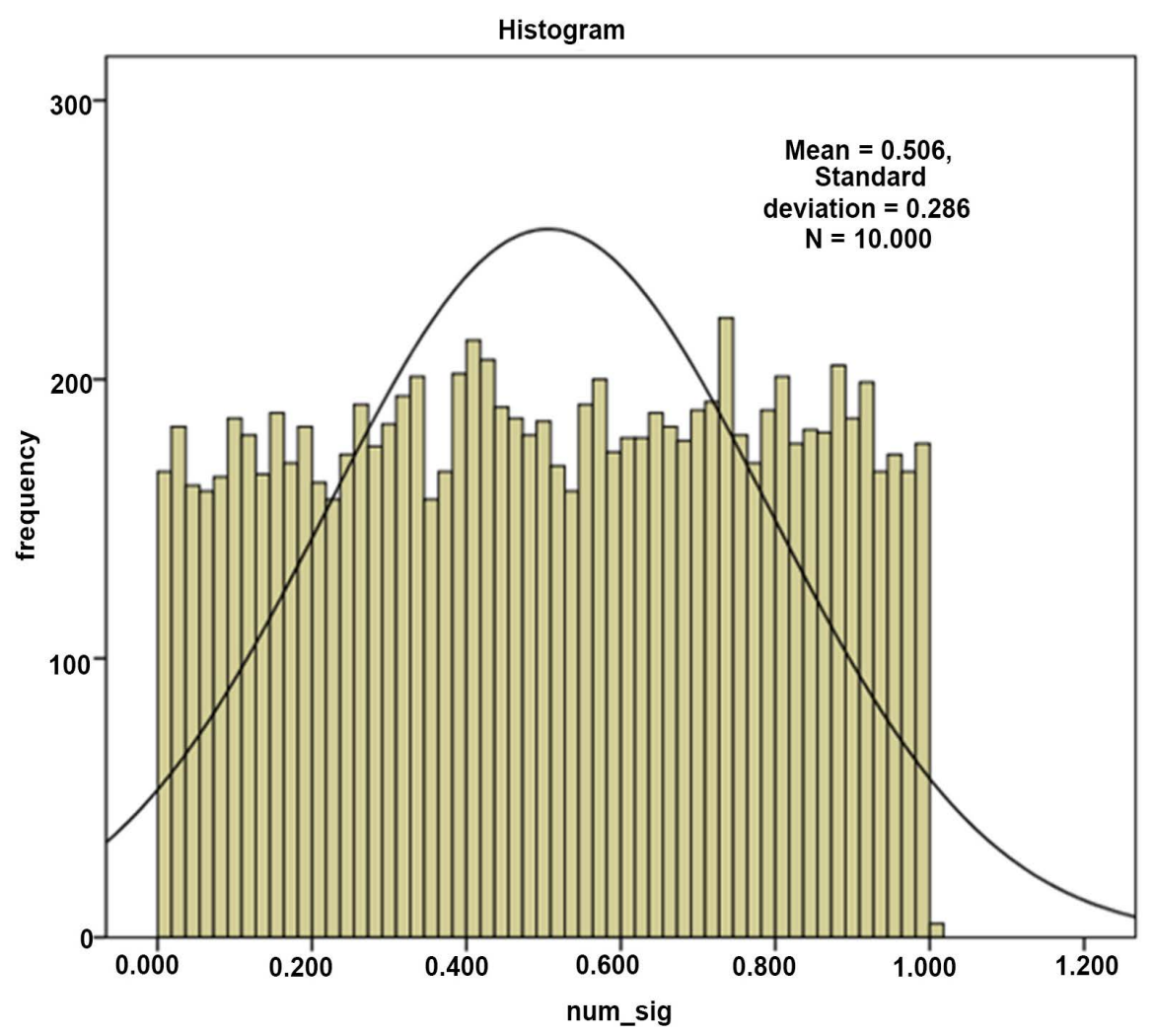

Figure 3. Cumulative distribution of sig values obtained from hypothesis $1 \& 2$ placebo test.

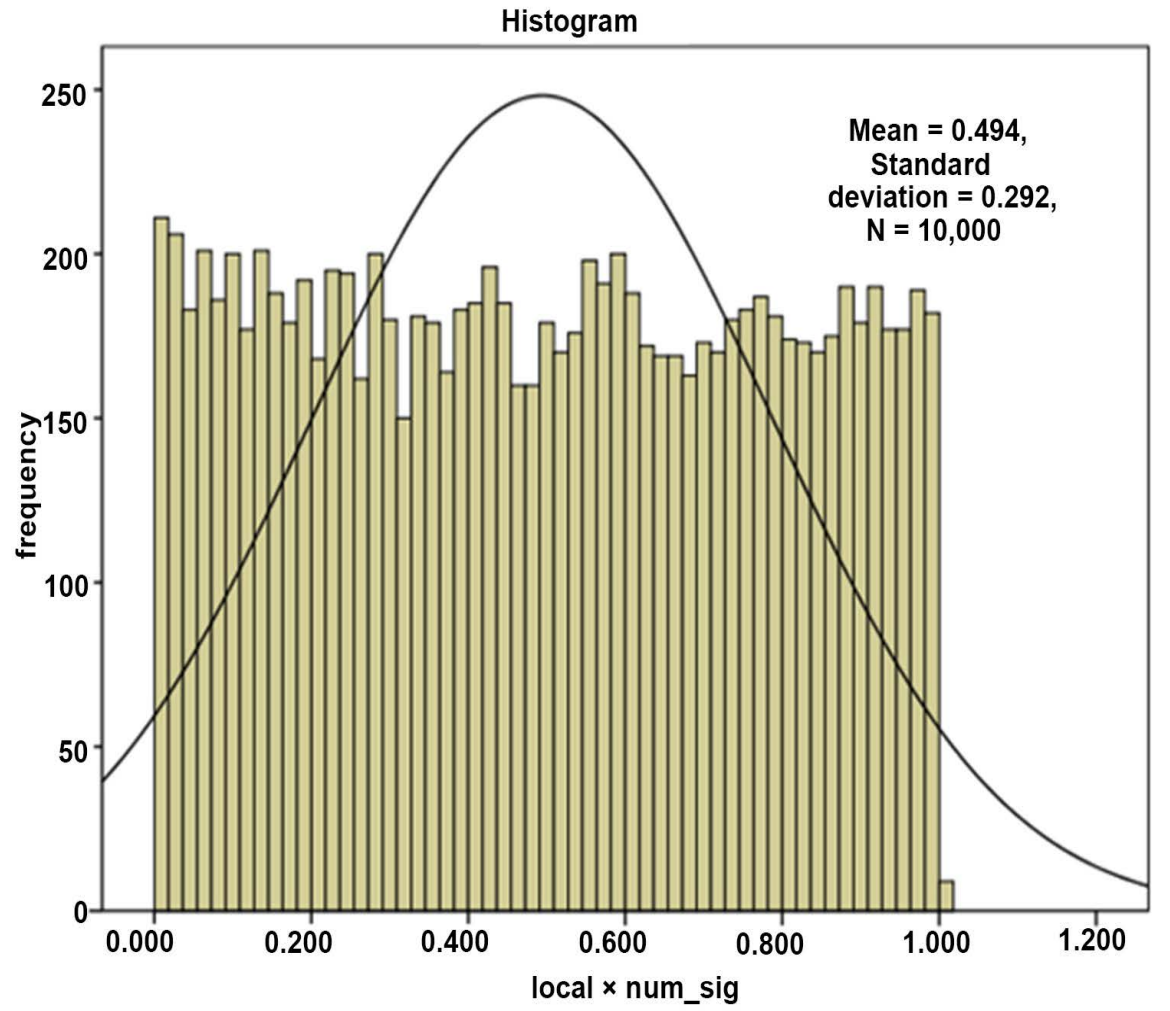

Figure 4. Cumulative distribution of sig values obtained from hypothesis 3 placebo test. 


\section{Conclusion and Recommendations}

In view of the lack of statistics on the number of accounting firms in different provinces and cities in different years, this paper selects the number of firms in December 2017, combined with the financial data of 2016 A-share listed companies, to conduct research on the number of regional firms and audit fees. The conclusions of the study are as follows: The number of accounting firms in the region is positively related to the audit fees. The more the number of firms, the higher the audit fees; whether the local firm does not affect the audit fee, but if the local audit is selected, the number of firms will be strengthened. The audit fees paid by listed companies in the region will increase as the number of firm increases. The increase in audit fees is the performance of high-quality audit. In the standardized audit market, the more the number of regional accounting firms, the more intense the competition, the more helpful the audit quality in the region. It is suggested that China's government system policy encourage the establishment of accounting firms, at the same time strengthen market supervision, improve the auditing information disclosure system, allow accounting firms to participate in healthy competition, and prevent the occurrence of vicious low-price competition, which will benefit the development of audit market. At the same time, from the research of this paper, we can see that the international four major and domestic top ten audit fees are higher. The size and brand of accounting firms have a significant impact on audit fees. China should speed up the pace of accounting firms to become bigger and stronger. Promote mergers and acquisitions between firms, carry out brand building, improve the quality of audit services, and thus improve the market competitiveness of local accounting firms in China.

\section{Conflicts of Interest}

The author declares no conflicts of interest regarding the publication of this paper.

\section{References}

[1] Simunic, D.A. (1980) The Pricing of Audit Services: Theory and Evidence. Journal of Accounting Research, 18, 161-190. https://doi.org/10.2307/2490397

[2] Francis, J. (1984) The Effect of Audit Firm Size on Audit Prices: A Study of the Australian Market. Journal of Accounting and Economies, 6, 133-151. https://doi.org/10.1016/0165-4101(84)90010-7

[3] Chen, P., Ezzamel, M. and Gwilliam, D. (1993) Determinants of Audit Fees for Quoted UK Companies. Journal of Business Finance Accounting, 20, 765-786. https://doi.org/10.1111/j.1468-5957.1993.tb00292.x

[4] Abbott, L.J., Parker, S., Peters, G.F. and Raghunandan, K. (2003) The Association between Audit Committee Characteristics and Audit Fees. Auditing. A Journal of Practice \& Theory, 22, 17-32. https://doi.org/10.2308/aud.2003.22.2.17

[5] Carcello, J.V., Hermanson, D.R., Neal, T.L. and Riley, R.A. (2002) Board Characteristics and Audit Fees. Contemporary Accounting Research, 19. 
[6] Wang, Z.L. (2002) Decisions on Audit Fees and Audit Quality: Evidence from Chinese Listed Companies. PhD Thesis, Shanghai University of Finance and Economics, Shanghai.

[7] Liu, B., Ye, J.Z. and Liao, Y.Y. (2003) Empirical Study on the Influencing Factors of Audit Fees of China's Listed Companies-Evidence from Shenzhen-Shanghai Annual Report. Audit Research, No. 1, 44-47.

[8] Han, H.J. and Zhou, S.C. (2003) Research on Accountant Compensation in China's Securities Market-Analysis of Empirical Data of Listed Companies. Management World, No. 2, 15-22.

[9] Qi, J.N., Chen, H.L. and Zhang, Y. (2004) Firm Size, Brand, Price and Audit Quality: "International Four" China Audit Market Charging and Quality Research. Audit Research, No. 3, 59-64.

[10] Zhu, X.P. and Yu, Q. (2004) Empirical Analysis of Factors Affecting Audit Fees in China. China Accounting Review, 2, 393-408.

[11] Lu, L.M. and Lu, Y. (2010) Research on the Influencing Factors of China's Independent Audit Fees-Evidence Based on Stock Market. Journal of Harbin University of Commerce, 12, 99-125.

[12] Wang, B. and Xin, Q.Q. (2010) Does the Audit of the Branch Affect Audit Quality and Audit Fees. Audit Research, No. 2, 70-76.

[13] Zhang, Q.F., Zhang, M. and Dai, J.J. (2006) A Review of Empirical Research on Audit Pricing in China. Accounting Research, No. 6, 87-93. 